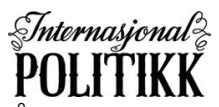

Årgang 74 | Nr. 4 | 2016 | ISSN 1891-5580

Leder

\section{Takk for oss!}

En knapp måned etter valget av Donald Trump som USAs neste president har spådommene om den liberale verdens endelikt og radikale utenrikspolitiske endringer stilnet noe. Det er blitt påpekt at valgkamp har sin egen logikk og at Trump kanskje vil moderere seg så fort han sitter i presidentstolen. Den amerikanske verdiarven vil innhente ham. I utenrikspolitikken vil han ikke bare måtte ta hensyn til republikanerne i Kongressen, han vil også måtte bryne seg på et profesjonelt kobbel av rådgivere og byråkrater i Pentagon og i State Department. Trump har særlig lite erfaring når det gjelder utenrikspolitikk og vil være mest opptatt av å tekkes sine velgere på hjemmebane. I sum vil kanskje de utenrikspolitiske konsekvensene bli mindre dramatiske enn hva mange har fryktet eller håpet.

Uavhengig av om kursjusteringer vil forekomme eller ikke, må Trumps retorikk i valgkampen tas på alvor. Hvordan (påtroppende) statsledere snakker om sin egen stat og sitt eget folk, hva og hvem de definerer som problemer, venner og fiender, former politikkens handlings- og mulighetsrom. Her trekker Trump på etablerte skillelinjer i sin fortelling om den amerikanske og globale virkeligheten, men han gjør dem skarpere og tilfører nye dimensjoner. Trump er først og fremst en populist. Han er, med professor Jan-Werner Müller ved Princeton Universitys ord, en politiker som hevder å representere det «egentlige» USA, samtidig som han signaliserer hvilke grupper som legitimt tilhører folket og hvilke som burde ekskluderes; populister styrer og forener nettopp gjennom slik ekskludering.

Slik sett er ikke Trump et nytt fenomen, men en del av en trend. Den russiske president Putin passer også godt inn i definisjonen av en populist og har gjort det i mange år. Det gjør også mange av Europas fremadstormende høyrenasjonale politikere. Samtidig er det foruroligende å observere at mange etablerte politiske partier i Vesten også beveger seg i retning av populisme for ikke å tape terreng. Med Trumps valgseier og ikke minst med den uverdige valgkampen (som også Hillary Clinton og massemedia må ta ansvaret for) kan en type politikk som forener noen ved å ekskludere andre ha blitt den nye normalen.

I USA som i Europa er islam og muslimer et lett bytte for slik eksklusjon gjennom påstanden om at disse utgjør et fremmedlegeme $i$ det «egentlige folket». Mange vil huske at Trump tidlig i valgkampen uttalte at han ville nekte alle muslimer adgang til USA. Skepsis mot islam og muslimer har lenge stått sentralt i det politiske ordskiftet i Europa, og særlig i høyrepopulistiske partiers retorikk. I vårt naboland Sverige vakte det for eksempel oppsikt da Sverigedemokratenes leder for noen år siden omtalte muslimer som «den verste trussel mot Sverige siden annen verdenskrig».

Fokusspalten i dette nummeret av IP belyser nettopp islams rolle i Europa, både historisk og i dag. Religionshistoriker Egil Asprem viser at islam ikke er noe nytt og 
fremmed for Europa i historisk perspektiv, og avviser påstanden om at islam trenger en «reformasjon» lik den kristendommen gjennomgikk i Europa. Cecilie Endresen, også hun religionshistoriker, tar for seg moderniserings- og sekulariseringsprosesser i Sørøst-Europa i et lengre historisk perspektiv. Hun påpeker at det der finnes store muslimske grupper som lenge har praktisert et skille mellom religion og politikk. Terrorforsker Anne Stenersen gir oss en forklaring på hvorfor jihadistiske terrorgrupper ønsker å angripe Europa. Hun mener voldsbruken må forstås som motivert ut fra et ønske om å forsvare muslimske land, heller enn å bringe islam til Europa.

Vi har også gleden av å presentere tre fagartikler: Camilla Tanna Nørup Sørensen diskuterer i sin artikkel hvordan den danske verdibaserte utenrikspolitikken formes av endringer i verdensordenen. Med vekt på hvordan Danmark forholder seg til Kina som stormakt argumenterer Sørensen for at Danmarks verdiaktivisme er i ferd med å reduseres til en svak understrømning i utenrikspolitikken. I utgavens andre fagartikkel argumenterer Håvard Rustad Markussen for at den norske TV-serien «Okkupert» (2015), hvis utgangspunkt er at Norge legges under russisk kontroll, bidro til å forsterke bildet av Russland som «kvalitativt annerledes enn Vesten». Sikkerhetspolitikk står i sentrum også for utgavens tredje og siste fagartikkel. Lilly Pijnenburg Muller stiller der spørsmål ved hvor effektivt samarbeidet mellom offentlig og privat sektor har vært $\mathrm{i}$ arbeidet med å skape et sikkert cyberspace.

Dette nummeret markerer veis ende for denne $I P$-redaksjonen. Etter fem år $\mathrm{i}$ redaktørstolen gir vi nå stafettpinnen videre.

Da vi overtok redaktøransvaret i 2012 så vi det som en hovedoppgave å ivareta IPs rennommé som det ledende skandinaviskspråklige fagtidsskriftet innen studiet av internasjonal politikk. I en tid der endring gjerne fremstilles som eneste gyldige valuta, oppfattet vi det som vår kanskje fremste oppgave å forvalte og foredle et allerede verdifullt produkt. Vi ville overraske, utfordre og inspirere leserne, men vi var opptatte av at $I P$ skulle være gjenkjennelig i form og innhold.

Når vi nå har gleden av å se tilbake på fem årganger og tjue utgaver med $I P$-stoff tillater vi oss å være litt stolte. Fokusspaltene har dekket et bredt spekter av tema fra dyr og kjendiser $\mathrm{i}$ internasjonal politikk via global helse til de nordiske lands forhold til Kina. Vi har etterstrebet faglig mangfold, teoretisk og empirisk. Vi har hatt bidragsytere fra ulike fagdisipliner, fra både akademiker- og praktikersiden og fra alle de skandinaviske landene. Vi har økt andelen kvinnelige bidragsytere til fokusspalten betraktelig, og vi har videreført Ordingprisen som en inngangsport for nye stemmer i faget.

Den største endringen i vår redaktørperiode skyldes imidlertid ikke redaksjonelle prioriteringer. Etter 73 årganger opphørte papirutgaven, og fra og med januar i år er IP et heldigitalt, Open Access-tidsskrift. Ett år og fire utgaver senere er det for tidlig å trekke bastante konklusjoner, men vi observerer med glede at nedlastningstallene for våre første heldigitale utgaver ligger på nivå med anerkjente internasjonale tidsskrifter.

Overgangen til Open Access har gjort det mulig å nå flere lesere, og å styrke IPs tilstedeværelse i sosiale medier og i den løpende politiske debatten. Det smaker utvilsomt bedre å sende potensielle lesere videre til en åpent tilgjengelig tekst, enn til en betalingsmur. IP har i skrivende stund over tusen følgere på Facebook, og flere av 
våre fagartikler og fokusspalter har ført til debatt $\mathrm{i}$ de store norske mediene. Lanseringsseminarene våre har også hatt overveldende godt oppmøte. Vi opplever at vi har lykkes med vår målsetning om å bringe $I P$-stoff inn i den offentlige debatten og med å nå lesere på nye flater.

Det er ikke mulig å lage et godt tidsskrift uten støttespillere. Vi vil benytte anledningen til å takke Norges forskningsråd for finansieringsstøtte, og NUPI og våre to forlag - først Universitetsforlaget og så Cappelen Damm Akademisk - for godt samarbeid gjennom de siste årene. En stor takk også til redaksjonsrådet vårt, og til våre eminente bokredaktører Morten Skumsrud Andersen, Minda Holm og Bjørnar Sverdrup-Thygeson.

Dernest ønsker vi å rette en stor takk til alle de flotte fagpersonene - forfattere og fagfeller - som vi har hatt gleden av å stifte bekjentskap med og samarbeide gjennom disse årene. Dere har utvidet vår faglige horisont og gitt oss nye innsikter. Og endelig, tusen takk til alle leserne som har fulgt oss på veien - både dere som trofast har fulgt oss fra utgave til utgave, og dere som har klikket innom fra tid til annen.

Vi overlater et tidsskrift med vind i seilene og i sin aller beste alder til en ny og inspirert redaksjon. Vi vet at Benjamin de Carvalho, Minda Holm og Niels Schia gleder seg til og brenner for oppgaven. Vi er trygge på at de vil gjøre en utmerket jobb, og gleder oss til å følge med IP videre som lesere!

Takk for oss, 